\title{
Examining geological controls on Baseflow Index (BFI) using regression analysis: an illustration from the Thames Basin, UK.
}

\author{
J. P. Bloomfield ${ }^{1 *}$, D. J. Allen ${ }^{1} \&$ K. J. Griffiths ${ }^{1}$ \\ ${ }^{1}$ British Geological Survey, Maclean Building, Crowmarsh Gifford, Wallingford, \\ Oxfordshire, OX10 8BB, UK. \\ *Corresponding author: \\ Dr John Paul Bloomfield, British Geological Survey, Maclean Building, Crowmarsh \\ Gifford, Wallingford, Oxfordshire, OX10 8BB, UK. \\ Tel. +44 (0)1491 692310 (direct) \\ Tel. +44 (0)1491 838800 (switchboard) \\ Fax. $+44(0) 1491692345$ \\ E-mail jpb@bgs.ac.uk
}

\begin{abstract}
Linear regression methods can be used to quantify geological controls on baseflow index (BFI). This is illustrated using an example from the Thames Basin, UK. Two approaches have been adopted. The areal extents of geological classes based on lithostratigraphic and hydrogeological classification schemes have been correlated with BFI for 44 'natural' catchments from the Thames Basin. When regression models are built using lithostratigraphic classes that include a constant term then the model is shown to have some physical meaning and the relative influence of the different geological classes on BFI can be quantified. For example, the regression constants for two such models, 0.64 and 0.69 , are consistent with the mean observed BFI (0.65) for the Thames Basin, and the signs and relative magnitudes of the regression coefficients for each of the lithostratigraphic classes are consistent with the hydrogeology of the basin. In addition, regression coefficients for the lithostratigraphic classes scale linearly with estimates of $\log _{10}$ hydraulic conductivity for each lithological class. When a regression is built using a hydrogeological classification scheme with no constant term, the model does not have any physical meaning, but it has a relatively high adjusted $R^{2}$ value and because of the continuous coverage of the hydrogeological classification scheme, the model can be used for predictive purposes. A model calibrated on the 44 'natural' catchments and using four hydrogeological classes (low permeability surficial deposits, consolidated aquitards, fractured aquifers and intergranular aquifers) is shown to perform as well as a model based on a hydrology of soil types (BFIHOST) scheme in predicting BFI in the Thames Basin. Validation of this model using 110 other 'variably impacted' catchments in the Basin shows that there is a correlation between modelled and observed BFI. Where the observed BFI is significantly higher than modelled BFI the deviations can be explained by an exogenous factor, catchment urban area. It is inferred that this is may be due influences from sewage discharge, mains leakage, and leakage from septic tanks.
\end{abstract}

KEYWORDS: baseflow; Baseflow Index; BFI; BFIHOST; groundwater; hydraulic conductivity; Thames Basin 


\section{INTRODUCTION}

Hydrological characteristics of catchments, such as baseflow, or measures of high and low stream flow, may be estimated using a variety of physical descriptors (Nash, 1960; Hall, 1968; Nathan and McMahon, 1990a; 1992). These descriptors include physiographic and climatological parameters and may involve geologically or hydrogeologically related parameters. A hydrogeological characteristic of catchments that has been the focus of a number of studies, particularly in the context of modelling ungauged catchments, is Base Flow Index (BFI). BFI is the long-term ratio of baseflow to total stream flow and thus represents the slow or delayed contribution to river flow and may be influenced to a significant extent by catchment geology. However, to date the relationship between catchment geology and BFI has not been quantified in a systematic manner. Even though there is a tacit assumption that the underlying geology influences baseflow, previous studies that estimate BFI typically simplify the effect of catchment geology to a parameter that represents the fractional area of aquifers in a catchment (Nathan et al., 1996; Sefton and Howarth, 1998; Mwakalila et al., 2002; Mwakalila, 2003; Abebe and Foerch, 2006; Santhi et al., 2008). Some studies have adopted a slightly more refined approach to include a number of discrete geologies as physical catchment descriptors (Nathan and McMahon, 1990b; Lacey and Grayson, 1998; Mazvimavi et al. 2005), and, rather than use the areas of aquifers or different lithologies as catchment descriptors, Haberlandt et al. (2001) used the physical properties of the aquifers (effective porosity and saturated hydraulic conductivity). However, because, in addition to geological parameters, all these studies use non-geological parameters to estimate baseflow or BFI they cannot provide specific insights into the relationships between the geological characteristics of catchments and baseflow or BFI. The motivation for this study is to examine geological controls on BFI independent of other catchment factors.

A streamflow hydrograph describes the variation in the rate of flow of a stream with time and consists of four basic elements: direct surface runoff, interflow, groundwater flow or baseflow (Nash, 1960; Hall, 1968; Nathan and McMahon, 1990a; Eckhardt, 2008), and channel precipitation. In most hydrograph analyses, interflow and channel precipitation are grouped with direct runoff (unless there is a need to explicitly treat them independently) and the total runoff hydrograph is made up of the sum of surface runoff and discharge from saturated groundwater storage or baseflow (Nathan and McMahon, 1990a; Viessman and Lewis, 2002). The baseflow component of the hydrograph represents longer-term (weeks to months) changes in the regional groundwater head and flow system and typically varies in response to relatively long seasonal changes in saturated groundwater head driven by seasonal changes in factors such as evapotranspiration (Wittenburg and Silvapalan, 1999). BFI is defined as the difference in area under the baseflow hydrograph and total runoff hydrographs obtained by baseflow or hydrograph separation (Institute of Hydrology, 1980). There are a variety of graphical or manual methods of baseflow separation. For example, Viessman and Lewis (2002) describe five methods and Eckhardt (2008) has recently compared seven different automated methods. In each case the separation methods are designed to separate the fast component of flow from the slower baseflow component by identifying the onset of rising limbs in the total stream hydrograph and the end of direct surface runoff towards the end of a local peak in the total stream hydrograph. Regardless of the details of the method used, and as Eckhardt (2008) notes, since the true values of the baseflow index are always unknown it is not possible to identify which of the methods provides the 'best' estimates of BFI. 
Geological information, along with other variables, has been correlated with BFI using a range of approaches including: multiple linear regression techniques (Nathan et al., 1996; Lacey and Grayson, 1997; Mwakalila et al., 2002; Mazvimavi et al., 2005; Abebe and Foerch, 2006), neural network methods (Mazvimavi et al., 2005), and regional landscape mapping (Santhi et al., 2008). The fractional area of aquifers, or in some cases specific lithologies, typically shows some correlation with BFI. Lacey and Grayson (1997) demonstrated that there was a strong relationship between the combined geology-vegetation groups and BFI, but suggested that the groups also represented other factors such as climatic history, recharge capacity and transmissivity. Mazvimavi et al. (2005) found that geology was not a significant predictor of BFI in their study area, but concluded that this was due to groundwater in certain formations in their study area (several catchments in Tanzania) being relatively deep and disconnected from surface streams.

Soil data has also been used extensively in studies of baseflow and BFI in ungauged catchments as a surrogate for the underlying geology. The Institute of Hydrology low flow study developed the 'hydrology of soil types' (HOST) classification to estimate flow duration and flow frequency parameters (Gustard et al., 1992; Boorman et al., 1995). It consists of a grouping of soil associations into classes based on physical properties of soils and on their hydrogeological setting. Multivariate regression of soil type data against BFI data for representative catchments in the United Kingdom produced continuous BFI catchment characteristics scaled on continuous soil parameters, referred to as BFIHOST (Gustard et al. 1992; Boorman et al., 1995). The BFIHOST methodology and data have been used successfully in a number of studies (Boorman et al., 1995; Sefton and Howarth, 1998; Dunn and Lilly, 2001; Lee et al., 2005; Marechal and Holman, 2005; Young, 2006).

The present study uses a similar approach to BFIHOST, in that geological associations are grouped into classes, based on lithological or hydrogeological characteristics, which are then correlated with observed BFI. However, unlike the previous studies, including BFIHOST, where the aim was to build robust predictive models using sometimes very limited information, the central task of the present study is to quantify as fully as possible the relationship between geological or hydrogeological characteristics of an area and observed BFI independent of any other factors. This is possible in the Thames Basin because high quality geological mapping and river flow data are available. In this study, linear regression models have been used to quantify geological controls on BFI by correlating detailed 1:50000 scale geological mapping with BFI values for catchments with diverse geological and aquifer characteristics at the basin scale $\left(\sim 10000 \mathrm{~km}^{2}\right)$. There are two complementary aims for the work described in this paper. The first aim is to investigate if physically meaningful relationships between lithological characteristics of catchments and BFI can be quantified at the basin scale using regression methods. The second aim is to show how a geologically-based model of BFI can be used to produce continuous BFI catchment characteristics in a similar manner to BFIHOST. The models have been applied to the Thames Basin, UK, as a case-study. The approach, however, is not basin specific and the methodology description and discussion include generic observations related to the application of regression modelling to the quantification of geological controls on baseflow regardless of basin hydrology or geology. 


\section{STUDY AREA}

The Thames Basin, defined by the catchment of the River Thames and its tributaries, is situated in the south east of the United Kingdom (Figure 1a). For the purposes of this study the Thames Basin is defined by the Environment Agency's Thames River Basin District (Environment Agency, 2007). The source of the River Thames is in the Costwolds in Gloucestershire. The length of the river down to Teddington Lock, in west London, is approximately $235 \mathrm{~km}$, and the area of the Basin is about $16100 \mathrm{~km}^{2}$. Teddington Lock is the lowest flow gauging station on the River Thames and marks the non-tidal limit of the river. Mean annual rainfall varies across the Thames Basin from about 600 to $900 \mathrm{~mm}$ and the mean flow at Teddington Lock is about $78 \mathrm{~m}^{3} \mathrm{~s}^{-1}$ (Natural Environment Research Council, 2003).

The Thames Basin is underlain by a thick sequence of Mesozoic to Recent rocks that can be divided into three broad zones based on geological structure: the Midlands Shelf to the northwest; the London Basin in the central area; and the Wealden Anticline to the southeast (Figure 1b), each with their own characteristic lithostratigraphy. The Midlands Shelf consists of a sequence of Jurassic rocks (including oolitic limestones and clays), Cretaceous and Palaeogene rocks (including the Upper Cretaceous Chalk, the major aquifer in the Basin) are exposed in the London Basin, and a Lower Cretaceous sequence of clays and sands outcrop in the structurally distinct Wealden Anticline in the southeast of the Thames Basin. Palaeogene to Recent surficial deposits can be found throughout the Thames Basin across all three of the structural zones.

The western parts of the Thames Basin are predominantly rural, whereas, the highly urbanised area of Greater London is located in the central and eastern part of the Basin and is home to about 13 million people. Just over $40 \%$ of public water supplies in the Basin, equivalent to $\sim 2.25$ million $\mathrm{m}^{3} / \mathrm{d}$, come from groundwater, mainly from the Chalk aquifer.

There is a long history of investigations into the water resources of the Basin and the system is highly regulated. However, there is only one basin-wide study of the relationships between groundwater and surface water in the peer-reviewed literature (Andrews, 1962). Andrews (1962) investigated, at a basin scale, the geological controls on the nature of groundwater discharge to the Thames above Teddington Lock. For example, based on expressions for natural recession of groundwater discharge at Teddington Lock and at Days Weir, Andrews was able to show that the rate of groundwater flow at Days Weir diminishes 1.7 times faster than at Teddington Lock. From gaugings above Days Weir, Andrews estimated that the yield per unit area of the Jurassic limestones is about $25 \%$ higher than that from the Chalk, but that the limestones give up water more quickly and the summer and autumn discharges fall below those from the Chalk.

\section{MODEL METHODOLOGY}

Three least squares regression models are described in this paper. Two related stepwise multiple linear regression models, Models $1 \mathrm{a}$ and $1 \mathrm{~b}$, have been developed to quantify the relative influence of the fractional areas of lithostratigraphic classes on observed BFIs. A third model, Model 2, has been developed to investigate whether regression models based on an alternative hydrogeologically-based classification scheme can be used to produce continuous characteristics, similar to BFIHOST, that 
adequately predict BFI across the Thames Basin. The lithostratigraphic and hydrogeological classification schemes (Table 1) for all regression models were developed and selected iteratively as part of the regression modelling process as illustrated schematically in Figure 2. The following sections describe how the catchments were selected; how the BFI data used in the study was obtained; how the geological and hydrogeological parameters used in the regression models were derived, and finally; the regression techniques that were used. The steps in the model methodology referred to in this section relate to the numbered steps shown in Figure 2.

\section{Selection of catchments}

Based on information for available gauging stations in the Thames Basin (Natural Environment Research Council, 2003), 154 catchments were initially selected for use in this study. The successful identification of multivariate relationships between stream flow characteristics, such as BFI, and catchment characteristics requires good quality data from catchments where the flow regimes are relatively natural (Gustard et al 1992). However, this is particularly problematic in a basin like the Thames Basin where artificial influences and anthropogenic stresses and impacts, such as river regulation measures, river and groundwater abstraction, conjunctive use schemes and effluent discharge to rivers are locally significant. Consequently, the 154 catchments were screened to remove those with poor quality records and or significant anthropogenic influences. The screening criteria developed for the Institute of Hydrology low flow estimation programme for the United Kingdom (Gustard et al, 1992) have been used to identify the sub-set of catchments for the regression modelling.

Following this screening, 44 relatively 'natural' catchments with good or adequate quality flow data were identified to be used to calibrate the regression models. The location of these catchments is shown in Figure 1a. The remaining 110 catchments have been used to validate Model 2. The 44 calibration catchments cover $\sim 7800 \mathrm{~km}^{2}$, equivalent to about $48 \%$ of the area of the Thames Basin, their areas are approximately log-normally distributed, and they range in size from 12 to $1016 \mathrm{~km}^{2}$ with a geometric mean of $\sim 103 \mathrm{~km}^{2}$. Based on a multi-scale typology classification system for groundwater-surface water interaction developed by Dahl et al (2007), the catchments in this study broadly fall into a 'landscape type' category, where groundwater flow systems are assumed to be influenced primarily by regional geomorphology, hydrogeological setting and aquifer structure and heterogeneity rather than specific riparian zone processes.

\section{BFI data}

BFI data were taken from the Hydrometric Register for the United Kingdom (Natural Environment Research Council, 2003). BFI was calculated using the UKIH method (Gustard et al., 1992; Natural Environment Research Council, 2003). In this method, for each stream hydrograph minima in five-day non-overlapping consecutive periods are identified and then searched for turning points. The turning points are connected to obtain the baseflow hydrograph which is constrained to equal the observed hydrograph ordinate on any day when the separated hydrograph exceeds the observed. $\mathrm{BFI}$ is then calculated as the ratio of the volume beneath the baseflow line between the first and last turning points. BFI is based on a separation of the entire record for a flow gauge where typical flow records are greater than five years (Natural 
Environment Research Council, 2003). Piggott et al. (2005) have suggested minor improvements to the Institute of Hydrology procedure that take into account effects associated with different starting points for the analysis of the five-day nonoverlapping periods and the calculation of values of baseflow that exceed corresponding values of stream flow. The differences in BFI estimates using the Institute of Hydrology method and the revised method of Piggott et al. (2005) are relatively small (typically up to 5\% of baseflow) and the average of the difference is approximately zero. As these errors are small, the published Institute of Hydrology BFI data have been used in this study (Natural Environment Research Council, 2003). Table 2 shows summary statistics for the BFIs for the 44 catchments used to calibrate the regression models.

\section{Identification of geological and hydrogeological parameters}

The lithostratigraphic classification scheme for Models $1 \mathrm{a}$ and $1 \mathrm{~b}$ and the hydrogeological classification scheme for Model 2 are both based on the same 1:50000 scale digital geological map of the Thames Basin. The geological data were taken from the British Geological Survey's 1:50000 scale digital geology data set of the United Kingdom (British Geological Survey, 2008). The map shows $>200$ named units exposed at the land surface in the Thames Basin (step 1), many of which are local units that cover only a few square kilometres, such as local river terrace (sand and gravel) deposits. Consequently, it was necessary to reduce the number of geological classes to ensure that the regression models were tractable, while at the same time allowing a sufficient number of geological classes to characterise the geological and hydrogeological diversity of the Thames Basin. The geological classes were grouped based on expert judgement (step 2). The following approach was used:

- Define a target for the number of lithological classes. In the case of the present study an initial target of 20 to 30 lithological classes was set (to be broadly comparable with the 29 classes used in the BFIHOST scheme Gustard et al., 1992; Boorman et al., 1995).

- Group the 1:50000 geology classes into internally consistent lithologies based on prior knowledge of the degree and nature of lithological variability in the Basin. For the purposes of this study, internally consistent was taken to mean that at least $85 \%$ or more of the class by area consisted of a similar lithotype based on the expert judgement of a hydrogeologist.

- Because the Thames Basin consists of a thick sequence of sedimentary rocks with no intrusive rocks, and because there is no major faulting in the Basin at surface, the classes could be based on the stratigraphic column and the hydrogeologist started the grouping exercise with the oldest formations and worked progressively up the stratigraphic column. As a consequence, stratigraphically neighbouring groups had to be lithologically distinct. In practice this meant that stratigraphically alternating chronologically distinct units dominated by alternating carbonate, clay and sandstone lithologies were identified.

- Two hydrogeologists were independently set the task of grouping the lithologies. The two lithological classification schemes were then compared. There were trivial differences between the two classification schemes which were then reconciled through discussion to produce the final lithological classes. 
This process resulted in 19 lithological classes being identified consisting of 15 classes of consolidated deposits and 4 classes of surficial deposits (step 3) shown in Figure 1b. Table 1 gives a brief description of the main geological and hydrogeological features of each the 19 lithological classes.

Based on the initial lithostratigraphic classification, preliminary data analysis was undertaken before the development of the regression models (step 4). Pearson correlation coefficients were calculated to check for any significant correlations between lithological classes and to characterise the relationships between the dependent and independent variables used in the regression. No transformations were applied to any of the independent variables. As a result of this preliminary data analysis, eight lithological classes were rejected from inclusion in regression Models $1 \mathrm{a}$ and $1 \mathrm{~b}$ and two classes were combined.

Eight geological classes (Bracklesham, Corallian, Gault, Gravels, Lias, Portland and Purbeck, Thanet and Clay-with-Flints) were rejected as they showed no consistent correlation between BFI and their catchment fractional areas due to the very limited number of catchments that contained these classes, or because two or more classes showed significant correlation, but the classes could not be combined due to significant lithological differences. In addition, two classes (the Greater and Inferior Oolites) were combined as they showed weak correlation (Pearson correlation coefficient of 0.57) are stratigraphically adjacent and show some hydrogeological similarity. Consequently, following the preliminary data analysis, 10 lithological classes were left for use in Models 1a and 1b (step 5).

The rationale for the hydrogeological classification was to start with the simplest scheme and to increase the complexity of the scheme until a satisfactory regression could be developed with adequate predictive capabilities (step 6). The simplest hydrogeological classification scheme is one based on a two-fold classification of aquifer and aquitard (Nathan et al., 1996; Sefton and Howarth, 1998; Mwakalila et al., 2002; Mwakalila, 2002; Abebe and Foerch, 2006). When models were built with either aquifer or aquitard fractional areas as the independent variable (both could not be used in the same regression as the two variables are co-correlated) they only explained about 70\% of the variation in BFI (step 7). The next step (step 8) was to increase the number of hydrogeological classes to a number that would be significant in a regression model but would also enable independent variables to be identified. The aquifers were divided into aquifers where fracture flow is dominant (e.g. limestone aquifers) and aquifers where intergranular flow is dominant (e.g. consolidated sandstone aquifers). The justification for this was that it was assumed that differences in the permeability and storage structure of these two types of aquifer may be usefully discriminated in the regression model. It was hypothesised that on average there may be more storage available in the intergranular aquifers compared with fractured aquifers, but that these aquifers would drain more slowly due to their relatively lower hydraulic conductivity. The aquitards were divided into two classes: thin relatively non-permeable surficial deposits, and consolidated aquitards. Again, the justification for this distinction was that the two types of aquitard may show significantly different storage, hydraulic conductivity and drainage characteristics.

The 19 lithological classes were then mapped onto the four hydrogeological classes using expert judgement. This was a trivial task since, as noted previously, due 
to the simple sedimentary sequence in the Basin the lithostratigraphic classification had given rise to chronologically distinct units dominated by alternating carbonate, clay and sandstone lithologies and there was clear correspondence with the four hydrogeological classes. Table 1 shows how the initial 19 lithological classes (defined at step 3) have been mapped onto four hydrogeological classes: low permeability surficial deposits, aquitards, intergranular aquifers, and fractured aquifers at step 8. Pearson correlation coefficients were calculated for the four hydrogeological classes to test the degree of independence of the variables used in the regression. There were no significant correlations between hydrogeological classes. The spatial distribution of the four hydrogeological classes in the Thames Basin is shown in Figure 3.

BFI may be expected to correlate with the fractional volume of the hydrogeological classes within a catchment. However in the absence of a detailed 3-D geological model of the Basin, once the lithostratigraphic and hydrogeological classes had been identified, as a surrogate for fractional volume, the fraction by area of the classes in each of the 44 catchments was estimated using a GIS. Table 2 shows summary statistics for the fractional area data for the final 10 lithological classes used in regression Models 1a and 1b (step 5) and for the four hydrogeological classes used in regression Model 2 (step 9).

\section{Regression methodology}

An initial multiple least square regression model was built using the lithostratigraphic classification for the ten lithological classes (step 10) using the 44 calibration catchments. This regression model had an adjusted squared multiple $\mathrm{R}$ value of 0.85 and a standard error of estimate of 0.086 . However, a number of the coefficients were not significantly different from zero. So a stepwise regression model, Model 1a (step 11), was built based on the ten independent lithological classes. Parameters were removed during stepwise regression where their coefficients were not significantly different from zero at $90 \%$ confidence level. Jackknife (leave one out) resampling was performed on the result of the stepwise regression model, Model 1a, to investigate the sensitivity of the model to individual cases (catchments). Based on the results of the Model 1a jackknife, a further model, Model 1b (step 12), was built using the same geological classes as used in Model 1a, but with one lithological class (the Lower Greensand) removed. Model 2 was built by regressing data for the four hydrogeological classes onto the BFI data (step 9) using the 44 calibration catchments. A jackknife (leave one out) was performed on Model 2. In addition, bootstrap re-sampling (random resamples from the observed data) was performed on Model 2 to characterise the distribution of model coefficients and to assess usefulness of the coefficients for predictive modelling. Statistics from the regression coefficients obtained from the bootstrap resampling of Model 2 were used as the basis for Monte Carlo simulations to predict confidence bounds for the model predictions. Model 2 was validated using the 110 catchments assessed as being 'variably impacted' during the catchment selection process.

\section{RESULTS}

Tables 3a, 3b and 3c show the results for the regression models, Model 1a, $1 \mathrm{~b}$ and 2 respectively. Figure 4 shows modelled values of BFI plotted against observed BFI for the forty-four calibration catchments for Models 1a, 1b and 2. It also shows the distribution of residuals for Models $1 \mathrm{a}, 1 \mathrm{~b}$ and 2 as a function of the modelled values of BFI. 


\section{Model 1}

Model 1a shows that six of the ten lithological classes: Diamicton, Chalk, Lower Greensand, Thames, Weald Clay, and Oolites as well as the regression constant, have coefficients significantly different from zero. Model 1a explains about $88 \%$ of the variance in BFI in the 44 catchments with a low residual standard error (0.085) associated with the model (Table 3a). Figure 4 shows the good correlation between modelled and observed BFI using Model 1a. However, jackknife (leave one out) resampling of Model 1a indicated that the model may be sensitive to the Lower Greensand variable in one particular case. A co-efficient for Lower Greensand of 0.107 was obtained in one case during jackknife resampling when the mean and standard deviation of the coefficients for Lower Greensand for the jackknife samples are 0.226 and 0.021 respectively. Consequently, a second regression model, Model $1 \mathrm{~b}$ (Table 3b), was built with the Lower Greensand variable removed to see if this produced an improved model. Model 1b explains a similar level of variance in BFI (88\%) to Model 1a with a similar low residual standard error (0.088), it also shows a good correlation between the modelled and observed BFI (Figure 4).

Plots of residuals for Models 1a and 1b qualitatively show homoscedasticity (Figure 4), there is no significant autocorrelation present in the residuals, and the residuals are broadly normally distributed. One-way Kolmogorov-Smirnov tests on the distribution of the residuals shows normal distributions with probabilities of 0.79 and 0.95 for Models $1 \mathrm{a}$ and $1 \mathrm{~b}$ respectively. In summary, both models have the same adjusted squared multiple $\mathrm{R}$ value while Model 1a has a slightly lower residual standard error than Model 1b. Although jackknife results for Model 1a indicate that it may be sensitive to a single anomalous class (catchment) associated with a high fractional area of Lower Greensand, removal of the Lower Greensand variable does not change the overall form or performance of the regression (Figure 4).

\section{Model 1 validation}

The regression constants from Model 1a and Model 1b, 0.64 and 0.69 respectively (Tables 3a and 3b), are representative values of BFI for the 44 catchments used in the calibration, while the coefficients of the lithological classes in the regression models indicate the degree of departure from this typical value of BFI due to each geological class. The values for the constants of the two models are consistent both with the mean value for the 44 catchments used in the calibration (0.65) and with the BFI at Teddington Lock (0.64), the lowest gauge in the Basin. It is inferred from the similarity between the model constants and observed mean BFI value and the value for BFI at Teddington Lock that the regression models have some physical meaning. This is supported by the observation that the significant lithological classes in the models, the signs of their coefficients and the relative magnitudes of the coefficients are all consistent with an understanding of the hydrogeology of the Basin.

Ten lithological classes were used as the input for the stepwise regression (Model 1a) and six classes, Diamicton, Chalk, Lower Greensand, Thames Clay, Weald Clay, and Oolites, were found to be significant. These lithological classes cover just over $50 \%$ of the area of the Basin (about half of the remaining area is covered by thin shallow deposits such as sands and gravels $~ 10 \%$, alluvium $\sim 9 \%$, and the Clay-with-Flints $~ 5 \%$ ) and include the Chalk, the most important aquifer in the Basin (Allen et al 1997, Jones et al 2000), as well as two other major aquifers, the Oolites, and, in Model 1a, the Lower Greensand. They also include the single most 
extensive aquitard in the Basin, the London Clay (part of the 'Thames' lithological class, Table 1). The signs and magnitudes of the coefficients for each of the lithological classes in Models $1 \mathrm{a}$ and $1 \mathrm{~b}$ are consistent with their hydrogeological characteristics. The Chalk and Oolite classes have positive coefficients as would be expected of aquifers, while the Diamicton, Thames and Weald Clay classes represent aquitards and have negative coefficients. The Chalk co-efficient is greater than that for the Oolites and this is consistent with the observations of Andrews (1962) that groundwater discharges from the Jurassic Limestones above Days Weir yield water more quickly than the Chalk in the Lower Thames. It is interesting to note that Diamicton is identified as having a significant negative co-efficient in Models 1a and 1b. Diamicton is not a regionally significant aquitard, such as the London Clay and the Weald Clay. It is a stiff, brown, yellow and grey mottled sandy clay glacial till that covers mainly Chalk in the north east of the Basin, Figure 1b. Although it only reaches a maximum thickness of $\sim 25 \mathrm{~m}$ (Millward et al., 1987), the clay content of Diamicton appears to be sufficiently high to contribute to relatively low values of BFI in catchments where it is present.

If, as assumed, the regression models have some physical meaning, it should be possible to correlate the regression coefficients with aquifer properties for each of the lithological classes. Baseflow may be expected to scale with a parameter such as hydraulic diffusivity, $D \quad\left(\mathrm{~K} / \mathrm{S}_{\mathrm{S}}\right.$, where $\mathrm{K}$ is hydraulic conductivity and $\mathrm{S}_{\mathrm{S}}$ is specific storage). Since hydraulic conductivity is likely to range over many orders of magnitude, but specific yield for aquitard and aquifer materials typically ranges from 0 to $\sim 0.3$ (Freeze and Cherry, 1979), as a first approximation hydraulic conductivity is a good surrogate for hydraulic diffusivity and is an appropriate parameter to attempt to correlate with the regression coefficients.

Each geological class will have a range of hydraulic conductivities depending on the scale of observation (Neuman, 1990) and heterogeneities in their pore structure, fabrics and larger-scale lithological variations (e.g. Anderson, 1997). For the purposes of this study we have considered the range of hydraulic conductivities that could be expected as derived from a typical pumping test or at the river reach scale (i.e. a scale of $10 \mathrm{~s} \mathrm{~m}$ to $100 \mathrm{~s} \mathrm{~m}$ ) for each geological class. Table 5 lists representative values for hydraulic conductivity for each of the geological classes with notes on how the representative values were inferred. Hydraulic conductivity data from the Thames Basin is available for the Chalk, Lower Greendsand, Oolites and Thames classes. Representative values for Diamicton and Weald Clay have been taken from Freeze and Cherry (1979, Table 2.2).

Figure 6 is a plot of these representative values of hydraulic conductivities against the regression coefficients for each of the geological classes in Model 1a. Note that in Model 1a the coefficients for the Lower Greensand and the Oolites are almost identical as are their inferred representative hydraulic conductivities so the two points plot effectively on top of each other. The hydraulic conductivity of the Chalk is known to be relatively high in valleys and low under interfluves (Allen et al., 1997). This has been represented by the range bar for the Chalk in Figure 6. The large range bars on the hydraulic conductivity of the Diamicton and Weald Clay represent the range of values for the respective lithologies taken from Freeze and Cherry (1979, Table 2.2) with the representative value being taken as the median of the range. 
Figure 6 shows that there is a positive linear relationship between the regression coefficients and $\log _{10}$ hydraulic conductivity for the geological classes in Model 1a.

If the regression coefficients in Models $1 \mathrm{a}$ and $1 \mathrm{~b}$ indicate the degree of departure from the typical or basin wide value of BFI represented by the constant terms in the regressions, the hydraulic conductivity associated with a regression coefficient of zero in Figure 6 may represent a class-independent value of hydraulic conductivity for a basin. Based on Figure 6, a representative hydraulic conductivity in the range of $10^{-5}$ to $\sim 10^{-9} \mathrm{~m} / \mathrm{s}$ can be inferred for the Thames Basin as shown by the range of values defined by the dashed lines. This value is consistent (albeit towards the lower end of the range) with representative values for aquifers i.e. $10^{-1}$ to $10^{-8} \mathrm{~m} / \mathrm{s}$ (Manning and Ingebritsen, 1999, Figure 1), for estimated basin scale values of hydraulic conductivity, e.g. $10^{-7}$ to $10^{-11} \mathrm{~m} / \mathrm{s}$ (Willet and Chapman, 1989; Deming, 1993), and for modelled values of 'equivalent hydraulic conductivity' of heterogeneous sedimentary sequences, e.g. $10^{-7}$ to $10^{-8} \mathrm{~m} / \mathrm{s}$ (Zhang et al., 2007). Consequently, Figure 6 is taken as further support for the assertion that Models $1 \mathrm{a}$ and $1 \mathrm{~b}$ have physical meaning.

\section{Model 2}

Regression Model 2, Table 3c, shows that the coefficients for all four hydrogeological classes are significantly different from zero and that the model explains about $97 \%$ of the variance in BFI in the 44 catchments. A jackknife resample of Model 2 showed that the model is not sensitive to any particular cases. Figure 4 shows a good correlation between modelled and observed BFI based on Model 2. Residuals from Model 2 qualitatively show homoscedasticity (Figure 4), there is no significant autocorrelation in the residuals, and the residuals are broadly normally distributed. A one-way Kolmogorov-Smirnov test on the residuals indicates a normal distribution with a probability of 0.76 . In addition, no spatial correlation was seen in the distribution of the residuals for the cases (catchments across the Basin).

Bootstrap statistics were generated for the regression coefficients in Model 2 based on 10000 bootstrap samples each with 44 cases. Table 4 gives summary statistics for the results from the bootstrap resampling of Model 2. Confidence bounds have been calculated for the modelled BFI data for Model 2 based on the bootstrap statistics. Assuming a normal distribution for each coefficient and using the mean and standard deviation of each coefficient from the bootstrap resampling, Monte Carlo simulations were performed, based on 10000 simulations for each case (catchment), to produce a distribution of predicted BFI values. Figure 4 shows the confidence bounds on the modelled values of BFI based on 95\%tile and 5\%tile values for the Monte Carlo simulations using the bootstrap statistics. The range in predicted BFI values for a given case is relatively small (typically 0.05), and there is no significant correlation between width of the confidence bands and the observed BFI, indicating the robustness of Model 3 for predictive purposes.

\section{Model 2 validation}

As a validation of Model 2, BFI predicted using the hydrogeological classification scheme can be compared with BFI calculated using BFIHOST for the 44 calibration catchments (Marsh and Hannaford, 2008). Figure 5 is a plot of predicted BFI against observed BFI for the respective models. It shows that there are no systematic differences in the range or magnitude of predicted BFI between the two 
models across the range of observed BFIs. In addition, linear regressions through the predicted and observed data for each model have similar slopes and that the $90 \%$ confidence bounds for the two regression overlap (Figure 5), although BFIHOST systematically predicts slightly lower BFIs by about 0.06. From these observations, it is inferred that predictions of BFI based on the Model 2 hydrogeological classification scheme (this study) and BFIHOST are comparable and that Model 2 performs as well as BFIHOST as a predictive tool.

Unlike Models 1a and 1b, Model 2 provides continuous BFI catchment estimates scaled on the independent hydrogeological parameters (in a similar manner to BFIHOST, Gustard et al., 1992; Boorman et al., 1995). Because the four hydrogeological classes cover the whole of the Basin the model calibrated using the 44 baseline catchments, can be used to predict BFI values for the remaining 110 catchments in the Thames Basin. If, as has been assumed, the 44 catchments used for calibration of Model 2 are largely un-impacted by anthropogenic effects then the degree of deviation of observed BFI from modelled BFI in the other 110 catchments in the Thames Basin should be a function of exogenous factors not related simply to catchment hydrogeology, including anthropogenic factors. Any systematic deviations of observed from modelled BFI that can be correlated with non-hydrogeological factors would provide additional validation for the regression model.

Figure 7 shows predicted BFI, based on Model 2, as a function of observed BFI for the 110 catchments in the Thames Basin. As expected, there is a wider scatter of predicted values for the 110 catchments compared with the 44 calibration catchments (Figure 5) due to both poorer quality flow records and a range of artificial influences and anthropogenic stresses and impacts on baseflow. Despite the larger scatter in predictions, there is still a good positive correlation between predicted and observed BFI and this correlation can be used to identify outliers. Based on the difference between observed and modelled BFIs, outliers have been identified as being either greater than or less than one standard deviation of the mean difference, Figure 7. The cases where observed BFI is higher than modelled BFI indicate that there is an apparent excess of baseflow above that which would be expected under natural conditions. Conversely, the cases where observed BFI is lower than modelled BFI indicate that the river has lower baseflow than that which would be expected under natural conditions. But do these outliers show systematic relationships with any anthropogenic factors or other characteristics of the catchments? Land cover data are available for the catchments, including urban coverage (Centre for Ecology and Hydrology, 2008; Marsh and Hannaford, 2008), and for this study percentage urban area of the catchments has been taken as a surrogate for the degree of anthropogenic impact on the catchments. Figure 8 is a plot of observed BFI as a function of urban area for the two classes of outliers identified in Figure 7. For catchments where the observed BFI is significantly higher than the modelled BFI there is a good negative correlation over a wide range of BFIs, but there is no similar correlation between observed BFI and urban area for catchments where observed BFI is less than the modelled BFI.

A number of studies have shown that urbanisation may cause increased surface runoff in annual streamflow including an increased magnitude of peak runoff (Chin and Gregory, 2001; Rose and Peters, 2001; Burns et al., 2005). However, Burns et al. (2005) in a study of the effects of suburban development on runoff generation 
also noted that baseflow during dry periods was greatest in high-density residential catchments and attributed this to discharge of septic tank effluent through the shallow groundwater system to streams. Because the negative correlation between observed BFI and urban area (for catchments where BFI is higher than expected) identified by this study holds over a wide range of absolute values of BFI and urban area, a single factor is unlikely to influence this relationship. Consequently, it is inferred from Figure 8 that a number of factors may contribute to the 'excess' observed baseflow that could include sewage discharge, mains leakage, and leakage from septic tanks. However, it is clear from Figure 8 that factors directly associated with urbanisation are not related to the catchments that show unexpectedly low values of BFI. These catchments are mainly rural ( $<20 \%$ urban area), sometimes relatively small (on average $\sim 75 \mathrm{~km}^{2}$ ) and most are highly impacted by groundwater abstraction. Some are affected by sewage discharges and a few of them have notably poor flow records (Marsh and Hannaford, 2008). A combination of these and possibly other factors must account for their anomalously low values of BFI.

\section{DISCUSSION}

\section{Geological controls on BFI}

By regressing fractional areas of discrete lithologies within catchments onto BFI and by demonstrating that the resulting regression models have some physical meaning, this study has shown that BFI can be considered as an integrated expression of the fractional areas of discrete lithologies within catchments. This can be done because only geological factors were considered during model calibration enabling the role of geology to be quantified independent of other factors. However, it has previously been demonstrated, using a variety of methods, that other parameter sets, including topographic, soil, vegetational and climatic factors (Nathan et al., 1996; Sefton and Howarth, 1998; Mwakalila et al., 2002; Mwakalila, 2003; Abebe and Foerch, 2006; Santhi et al., 2008), can explain observed variations in BFI equally well. How can these observations be reconciled?

Lacey and Grayson (1998) note that 'geology affects baseflow in at least two ways. The first effect is direct: groundwater is stored in rocks ... and this contributes to baseflow. The second effect is the formation of soil: different types of rocks tends to produce different types and depths of soil ... and hence differences in recharge, groundwater and baseflow'. However, the interrelationships between geology and other catchment parameters are likely to be far more complex than described by Lacey and Grayson (Tetzlaff et al., 2008). The underlying lithological characteristics of a catchment certainly effect the nature and depth of soils, but these in turn can influence vegetation type, land cover and land use. The underlying lithological characteristics of the catchment will affect long-term weathering and hence physiographic characteristics of the catchment and this in turn will effect soil and veretation development and may even influence to some small extent the distribution and magnitude of precipitation across the catchment. A combination of all these interactions will influence the nature and extent of recharge to the aquifer and all these factors and interactions will have a bearing on baseflow and BFI as an empirical measure of baseflow. Given the above, it is reasonable to conceptualise the underlying geology in catchments, as characterised by lithological variations and the associated variations in hydraulic and storage characteristics of those formations across a catchment, as a primary factor in affecting baseflow and BFI. However, because of the complex interrelationships between different catchment parameters it is not 
possible to simply say that a measure of one parameter set, e.g. a geology or soils index, is responsible for a given percentage of the variation in BFI.

\section{A generic methodology}

It has been shown that regression methodologies can be used to describe physically meaningful relationships between litholgical characteristics of catchments and their associated BFI in the Thames Basin (Models 1a and 1b), and that a regression model relating hydrogeological characteristics of catchments to BFI (Model 2) can be used to produce continuous BFI catchment characteristics with useful predictive capabilities for the Thames Basin (in a manner similar to BFIHOST). The details of the methods used in this study are specific the Basin, however, the generic approach has a wider application to other basins.

For models based on a lithological classification scheme the first step is to identify the lithological classes to be used in the step-wise regression models. In this study we used an expert judgement approach, although, depending on the type and quality of geological mapping information available, statistical techniques such as cluster analysis could be used to help inform the initial classification scheme prior to regression modelling. This step could even be removed by using an all possible subsets regression approach to entirely automate the regression process. Where an expert judgement approach is used, this study shows that it is helpful to have explicit targets (number of classes), assessments undertaken by independent workers to compare resulting initial lithological classification schemes, and rules appropriate to the basin and stratigraphic sequence being assessed. The target for the initial number of lithological classes may be limited by the available geological mapping. For example, the British Geological Survey has published three digital geological maps that cover the Thames Basin at 1:625000, 1:250000 and 1:50000 scales. The 1:50000 scale map was used as this gave the best resolution to the geological linework when estimating fractional areas of geologies in different catchments. The 1:625000 mapping shows 17 lithological classes in the Thames Basin. If this had been the only mapping available then the first step, to identify the lithological classes to be used in the regression, would not have been needed as all the mapped units at 1:625000 could have been used in the stepwise regression, but the model would less accurately represent the fractional areas of the different lithological classes.

The particular rules used by the independent workers to establish the expert judgement-solicited initial lithological classification are particular to the Thames Basin, but a generic approach can be identified. As previously noted, because the Basin consists of a sequence of sedimentary rocks the classes was be based on the stratigraphic column, and, as a consequence, stratigraphically neighbouring groups had to be lithologically distinct. This scheme is broadly applicable, however, for other basins in other geological and tectonic settings, for example, where there are major faults that cut-out sections of the stratigraphy or where there are intrusive units, the simple grouping of stratigraphically neighbouring units into lithologically coherent classes is not possible. In this case the hydrogeologists need to develop specific rules related to the grouping of units associated with faulting or intrusions. For the Thames Basin lithological classes were defined on the degree of internal coherency of lithology. For sequences that are faulted or contain intrusions then similar considerations can apply except that stratigraphically-, lithologically- and structurallybased grouping schemes could be developed and combined. 
For the regression models based on a hydrogeological classification scheme it is necessary to identify hydrogeologically representative classes that are continuous over the entire basin. In this study we developed the most simple classification scheme for which a satisfactory regression could be developed with adequate predictive capabilities. This entailed identifying four hydrogeologicaly distinct classes and mapping the lithological classification onto those units. Because the lithological classification for the Thames Basin had produced a series of chronologically distinct units dominated by alternating carbonate, clay and sandstone lithologies the task was trivial. An alternative more generic approach would be to use standard hydrogeological mapping conventions (UNESCO, 1983) to identify the hydrogeological classes. This may give more than the four hydrogeological classes used in this study, but would enable a similar regression model to be built.

\section{SUMMARY}

Despite a common assumption that underlying geology in catchments influences baseflow, to date the relationship between catchment geology and BFI has not been quantified in a systematic manner. In this study, relationships between lithological characteristics of catchments and BFI are quantified at the basin scale by multiple linear regression methods using the Thames Basin, UK, as a case-study. Multiple linear regression methods have been used before to relate catchment parameters to $\mathrm{BFI}$, however, because these studies used geological and non-geological parameters to estimate BFI they cannot provide specific insights into the relationships between the geological characteristics of catchments and BFI.

Standard stepwise multiple linear regression methods are used in this study to relate geological and hydrogeological parameters to BFI. Two similar regression models have been developed to quantify the relative influence of the fractional areas in catchments of different lithostratigraphic classes to BFI, and a second model has been developed to quantify the relationship between a simple hydrogeological classification scheme and BFI. The latter enables continuous characteristics to be modelled across the Basin, in a manner similar to the BFIHOST methodology.

Results suggest that for linear regression models built using lithological classifications schemes a physically meaningful regression model can be obtained if a constant term is included in the regression. The models have been validated by comparing the regression constant with a BFI value for the outflow stream for the whole basin, and by comparing the regression coefficients for each of the lithological classes with the known hydrogeological characteristics of those lithologies across the basin. The coefficients were found to scale linearly with estimates of $\log _{10}$ hydraulic conductivity for each of the lithological classes.

For a linear regression model built using a simple four-fold hydrogeological classification scheme, the model provides continuous BFI catchment estimates that are comparable to those obtained by BFIHOST. The model based on the hydrogeological classification scheme was validated using 110 'variably impacted' catchments in the Thames Basin. Significant deviations between observed and modelled BFI can be explained in part by consideration of an exogenous variable to the model, urban area. For cases, where the observed BFI is significantly greater than the modelled BFI, i.e. for catchments where there is an apparent excess of baseflow, the BFI is negatively correlated with urban area. 
The study has shown that BFI can be considered as an integrated expression of the fractional areas of lithologies in catchments. Previous studies have shown that other parameter sets, including topographic, soil, vegetational and climatic factors can also explain observed variations in BFI equally well. Depsite the complex correlations and interdependencies between different catchment parameter sets catchment lithology can be considered a first order or primary factor in affecting baseflow and BFI.

This study describes an expert judgement approach to selecting the initial set of geological parameters to be used in the stepwise linear regression models. The approach is generic, and can be applied to basins with a range of geological and structural settings, however, other statistical methods could easily be substituted to obtain the initial geological parameters. For the regression models based on a hydrogeological classification scheme it is necessary to identify hydrogeologically representative classes that are continuous over the entire basin. In this study we developed the most simple classification scheme for which a satisfactory regression could be developed with adequate predictive capabilities. An alternative more generic approach would be to use classes associated with standard hydrogeological mapping conventions.

\section{ACKNOWLEDGEMENTS}

The authors would like to thank Milly Lewis and Mike Cheetham for help with the lithological classification used in the study and Jenny Cunningham for help with spatial data analysis. This paper is published with the permission of the Executive Director of the British Geological Survey (Natural Environment Research Council).

\section{REFERENCES}

Abebe, A., Foerch, G., 2006. Catchment characteristics as predictors of base flow index (BFI) in Wabi Shebele river basin, East Africa. In: Proceedings of the Conference on Prosperity and Poverty in a Globalized World Challenges for Agricultural Research, Tropentag, University of Bonn, October 2006. http://www.tropentag.de/2006/

Allen, D.J., Brewerton, L.J., Coleby, L.M., Gibbs, B.R., Lewis, M.A., MacDonald, A.M., Wagstaff, S.J., Williams, A.T., 1997. The physical properties of major aquifers in England and Wales. British Geological Survey Research Report WD/97/34, 312 pp.

Andreson, M.P., 1997. Characterization of geological heterogeneity. In Dagan, G. and Neuman, S. P. (Editors), Subsurface Flow and Transport: A Stochastic Approach: Cambridge University Press, pp.23-43.

Andrews, F.M., 1962. Some aspects of the hydrology of the Thames Basin. Proc. Inst. Civ. Eng., 21, 55-91.

British Geological Survey, 2008. DiGMap 1:50,000 digital map of the United Kingdom. http://www.bgs.ac.uk/products/digitalmaps/digmapgb_50.html

Boorman, D.B., Hollis, J.M., Lilly, A.. 1995. Hydrology of soil types: a hydrologically-based classification of the soils of the United Kingdom. Institute of Hydrology report no. 126. 
Bloomfield et al. published in Journal of Hydrology, 373, 164-176

Burns, D., Vitvar, T., McDonnell, J., Hassett, J., Duncan, J., Kendall, C. 2005. Effects of suburban development on runoff generation in the Croton River basin, New York, USA. Journal of Hydrology, 311, 266-281

Centre for Ecology and Hydrology, 2008. Catchment spatial information, UK National River Flow Archive.

http://www.ceh.ac.uk/data/nrfa/catchment_spatial_information.html

Chin, A., Gregory, K.J., 2001. Urbanization and adjustment of ephemeral stream channels. Ann. Assoc. Am. Geogr., 91 595-608

Dahl, M., Nilsson, B., Langhoff, J.H., Reefsgaard, J.C., 2007. Review of classification systems and new multi-scale typology of groundwater-surface water interaction. Journal of Hydrology, 344, 1-16.

Deming, D., 1993. Regional permeability estimates from investigations of coupled heat and groundwater flow, North Slope of Alaska. J. Geophys. Res., 98, 16,27116,286 .

Dunn, S.M., Lilly, A., 2001. Investigating the relationship between a soils classification and the spatial parameters of a conceptual catchment-scale hydrological model. Journal of Hydrology, 252, 157-173.

Eckhardt, K., 2008. A comparison of baseflow indices, which were calculated with seven different baseflow separation methods. Journal of Hydrology, 352(1-2), 168173.

Ellison, R.A., Woods, M.A., Allen, D.J., Forster, A., Pharoah, T.C., King, C., 2004. Geology of London. Memoir of the British Geological Survey, British Geological Survey, Keyworth, UK. ISBN 0852724780.

Environment Agency, 2007. Thames River Basin District. River Basin planning: working together. http://www.environmentagency.gov.uk/commondata/acrobat/th_wt_doc1_1815714.pdf

Freeze, R., Cherry, J.A., 1979. Groundwater. Published by Prentice-Hall Inc., New Jersey.

Gustard, A., Bullock, A., Dixon, J.M., 1992. Low flow estimation in the United Kingdom. Institute of Hydrology report number 108. ISBN 0948540451.

Haberlandt, U., Klocking, B., Krysanova, V., Becker, A., 2001. Regionalisation of the base flow index from dynamically simulated flow components - a case study in the Elbe River Basin. Journal of Hydrology, 248, 35-53.

Hall, F.R., 1968. Baseflow recession - a review. Water Resources Research, 4, 973983.

Institute of Hydrology, 1980. Low Flow Studies report. Wallingford, UK 
Bloomfield et al. published in Journal of Hydrology, 373, 164-176

Jones, H.K., Morris, B.L., Cheney, C.S., Brewerton, L.J., Merrin, P.D., Lewis, M.A., MacDonald, A.M., Coleby, L.M., Talbot, J.C., McKenzie, A.A., Bird, M.J., Cunningham, J.E, Robinson. V.K., 2004. The physical properties of minor aquifers in England and Wales. British Geological Survey Research Report WD/00/04. 234pp.

Lacey, G.C., Grayson, R.B., 1998. Relating baseflow to catchment properties in south-eastern Australia. Journal of Hydrology, 204, 231-250.

Lee, H., McKintyre, N., Wheater, H., Young, A., 2005. Selection of conceptual models for regionalisation of the rainfall-runoff relationship. Journal of Hydrology, 312, 125-147.

Manning, C.E, Ingerbritsen, S.E., 1999. Permeability of the continental crust: implications of geothermal data and metamorphic systems. Reviews of Geophysics, 31, 127-150.

Marechal, D,. Holman, I.P., 2005. Development and application of a soil classification-based conceptual catchment-scale hydrological model. Journal of Hydrology, 312, 277-293.

Marsh, T.J., Hannaford, J., (Eds.), 2008. UK Hydrometric Register. Hydrological data UK series. Centre for Ecology and Hydrology, 210pp.

Mazvimavi, D., Maijerink, A.M.J., Savenije, H.H.G., Stein, A., 2005. Prediction of flow characteristics using multiple regression and neural networks: A case study in Zimbabwe. Physics and Chemistry of the Earth, 30, 639-647.

Millward, D., Ellison, R.A., Lake, R.D., Moorlock, B.S.P., 1987. Geology of the country around Epping. Mem. Br. Geol. Surv., Sheet 240 (England and Wales), 80pp.

Mwakalila, S., 2003. Estimation of stream flows of ungauged catchments for river basin management. Physics and Chemistry of the Earth, 28, 935-942.

Mwakalila, S., Feyen, J., Wyseure, G., 2002. The influence of physical catchment properties on baseflow in semi-arid environments. Journal of Arid Environments, 52, 245-258.

Nash, J.E., 1960. A unit hydrograph study with particular reference to British catchments. Proc. ICE, 17, 249-282.

Nathan, R.J., Austin, K., Crawford, D. Jayasuriya, N., 1996. The estimation of monthly yield in ungauged catchments using a lumped conceptual model. Australian Journal of Water Resources, 1 (2), 65-74.

Nathan, R.J., McMahon, T.A., 1990a. Evaluation of automated techniques for baseflow and recession analysis. Water Resources Research, 26(7), 1465-1473.

Nathan, R.J., McMahon, T.A., 1990b. Identification of homogeneous regions for the purposes of regionalisation. Journal of Hydrology, 121, 217-238. 
Bloomfield et al. published in Journal of Hydrology, 373, 164-176

Nathan, R.J., McMahon, T.A., 1992. Estimating low flow characteristics in ungauged catchments. Water Resources Management, 6, 85-100.

Natural Environment Research Council, 2003. Hydrological data UK. Hydrometric Register and Statistics 1996-2000. ISBN 190374106 8. 208pp.

Neuman, S., 1990. Universal scaling of hydraulic conductivities and dispersivities in geologic media. Water Resources Research, 26(8), 1749-1758

Piggott, A.R., Moin, S., Southman, C., 2005. A revised approach to the UKIH method for the calculation of baseflow. Hydrological Sciences Journal, 50(5), 911-920.

Rose, S., Peters, N.E., 2001. Effects of urbanization on streamflow in the Atlanta area (Georgia, USA): a comparative hydrological approach. Hydrological Processes, 15, 1441-1457.

Santhi, C., Allen, P.M., Muttiah, R.S., Arnold, J.G. Tuppad, P., 2008. Regional estimation of base flow for the conterminous United States by hydraulic landscape regions, Journal of Hydrology, 351, 139-153.

Sefton, C.E.M., Howarth, S.M., 1998. Relationships between dynamic response characteristics and physical descriptors of catchments and physical descriptors of catchments in England and Wales. Journal of Hydrology, 211, 1-16.

Tetzlaff, D. , McDonnell, J.J., Uhlenbrook, S., McGuire, K.J., Bogaart, P.W., Naef, F., Baird, A.J., Dunn S.M., Soulsby C. 2008. Conceptualizing catchment processes: simply too complex. Hydrogeological Processes, 22, 1727-1730.

United Nations Educational, Scientific and Cultural Organization. International legend for hydrogeological maps. 1983. UNESCO report no. SC-84/WS/7, UNESO. http://unesdoc.unesco.org/images/0015/001584/158459eo.pdf

Viessman, W., Lewis, G.L., 2002. Introduction to Hydrology, Fifth Edition. Prentice Hall, New Jersey, USA.

Willet, S.D., and Chapman, D.S., 1989. Temperatures, fluid flow, and the thermal history of the Unita basin. In: Migrations of hydrocarbons in Sedimentary Basins (Ed. Beck, A.E., Garven, G., Stegena, L.), AGU, Washington, D.C. pp. 29-33.

Wittenburg, H., Silvapalan, M., 1999. Watershed groundwater balance estimation using streamflow recession analysis and baseflow separation. Journal of Hydrology, 219, 20-33.

Young, A.R., 2006. Streamflow simulation within UK ungauged catchments using a daily rainfall-runoff model. Journal of Hydrology, 320, 155-172.

Zhang, Y., Person, M., Gable, C.W., 2007. Representative hydraulic conductivity of hydrogeological units: Insights from an experimental stratigraphy. Journal of Hydrology, 339, 65-78. 
Bloomfield et al. published in Journal of Hydrology, 373, 164-176

\section{Tables}

Table 1. Description of main geological and hydrogeological features of the lithological classes. The hydrogeological classification used in the study is given in parenthesis after the name of each lithological class.

\begin{tabular}{|c|c|}
\hline Lithological class & Description \\
\hline \multicolumn{2}{|l|}{ Surficial deposits } \\
\hline $\begin{array}{l}\text { Alluvium } \\
\text { (low-permeability } \\
\text { surficial deposit) }\end{array}$ & $\begin{array}{l}\text { Recent unconsolidated deposits consisting of clay, silt, sand and gravel. Present in } \\
\text { many river valleys in the Basin. }\end{array}$ \\
\hline $\begin{array}{l}\text { Gravel } \\
\text { (intergranular } \\
\text { aquifer) }\end{array}$ & $\begin{array}{l}\text { Quaternary to Recent unconsolidated gravels and sands. Mainly present in river } \\
\text { valleys, although older River Terrace deposits and glaciofluvial deposits found } \\
\text { away from valley axes. Locally important aquifer particularly when in contact with } \\
\text { underlying Chalk aquifer. }\end{array}$ \\
\hline $\begin{array}{l}\text { Clay-with-Flints } \\
\text { (low-permeability } \\
\text { surficial deposit) }\end{array}$ & Stiff Clay-with-flints found as a weathered residual deposit derived from the Chalk. \\
\hline $\begin{array}{l}\text { Diamicton } \\
\text { (low-permeability } \\
\text { surficial deposit) }\end{array}$ & $\begin{array}{l}\text { Till of glacial origin. Unconsolidated, very poorly sorted deposit with significant clay } \\
\text { fraction. }\end{array}$ \\
\hline \multicolumn{2}{|l|}{ Consolidated units } \\
\hline $\begin{array}{l}\text { Ancholme } \\
\text { (aquitard) }\end{array}$ & $\begin{array}{l}\text { Ancholme Group, including the Oxford Clay, Kellaways Formation, Ampthill Clay } \\
\text { and Kimmeridge Clay. }\end{array}$ \\
\hline $\begin{array}{l}\text { Bagshot and } \\
\text { Bracklesham } \\
\text { (aquitard) }\end{array}$ & $\begin{array}{l}\text { Bagshot Formation and Bracklesham Group. Fine-grained sands with thin silt or } \\
\text { clay lenses. }\end{array}$ \\
\hline $\begin{array}{l}\text { Chalk } \\
\text { (fractured aquifer) }\end{array}$ & $\begin{array}{l}\text { The Chalk Group. Dual porosity limestone with local hardbands and marl seams. } \\
\text { The major aquifer in the Basin, with highest hydraulic conductivities associated } \\
\text { with the larger river valleys and lower hydraulic conductivity below interfluves and } \\
\text { with depth. Locally sub-karstic. }\end{array}$ \\
\hline $\begin{array}{l}\text { Corallian } \\
\text { (fractured aquifer) }\end{array}$ & $\begin{array}{l}\text { Corallian Group. Fine-grained calcareous sandstones and limestones. Local minor } \\
\text { aquifer. }\end{array}$ \\
\hline $\begin{array}{l}\text { Gault } \\
\text { (aquitard) }\end{array}$ & The Gault Formation. Grey mudstones and silty mudstones. Acts as an aquitard. \\
\hline $\begin{array}{l}\text { Lias } \\
\text { (aquitard) }\end{array}$ & Lias Group. Mainly clay aquitard. \\
\hline $\begin{array}{l}\text { Lower Greensand } \\
\text { (intergranular } \\
\text { aquifer) }\end{array}$ & $\begin{array}{l}\text { Lower Greensand Group. Variably cemented fine to medium-grained sandstones } \\
\text { with minor mudstones. A locally important aquifer in the Thames Basin. }\end{array}$ \\
\hline $\begin{array}{l}\text { Oolite, Greater } \\
\text { (fractured aquifer) }\end{array}$ & $\begin{array}{l}\text { The Great Oolite Group. Mixed lithologies dominated by oolitic and shelly } \\
\text { limestones with minor mudstones and silty and sandy limestones. Locally } \\
\text { important aquifer. }\end{array}$ \\
\hline $\begin{array}{l}\text { Oolite, Inferior } \\
\text { (fractured aquifer) }\end{array}$ & $\begin{array}{l}\text { The Inferior Oolite Group. Mixed lithologies dominated by oolitic and shelly } \\
\text { limestones with minor mudstones and silty and sandy limestones. Locally } \\
\text { important aquifer. }\end{array}$ \\
\hline $\begin{array}{l}\text { Portland and } \\
\text { Purbeck } \\
\text { (fractured aquifer) }\end{array}$ & $\begin{array}{l}\text { Portland and Purbeck Beds. Mixed lithologies containing marls, shelly and oolitic } \\
\text { limestones and local glauconitic sands. Local minor aquifer. }\end{array}$ \\
\hline $\begin{array}{l}\text { Thames } \\
\text { (aquitard) }\end{array}$ & $\begin{array}{l}\text { Thames Group, including the London Clay Formation. Clay, locally silty with fine } \\
\text { sands at base. Aquitard throughout the Basin, but more permeable westward. }\end{array}$ \\
\hline $\begin{array}{l}\text { Thanet } \\
\text { (low-permeability } \\
\text { surficial deposit) }\end{array}$ & $\begin{array}{l}\text { Lambeth Group (including the Reading Woolwich and Upnor Formations) and the } \\
\text { Thanet Sands Formation. Highly variable fine grained sands, mottled clays, flint } \\
\text { pebble beds and shelly clays. Aquitard or local minor aquifers depending on clay } \\
\text { content. }\end{array}$ \\
\hline $\begin{array}{l}\text { Upper Greensand } \\
\text { (intergranular } \\
\text { aquifer) }\end{array}$ & $\begin{array}{l}\text { The Upper Greensand Formation. Glauconitic, calcareous siltstones, sands and } \\
\text { sandstones, variably cemented. Locally may act as a minor aquifer. }\end{array}$ \\
\hline
\end{tabular}


Bloomfield et al. published in Journal of Hydrology, 373, 164-176

\begin{tabular}{|l|l|}
\hline $\begin{array}{l}\text { Weald Clay } \\
\text { (aquitard) }\end{array}$ & Weald Clay Formation. Mudstone. Aquitard. \\
\hline $\begin{array}{l}\text { Wealden Sand } \\
\text { (intergranular } \\
\text { aquifer) }\end{array}$ & Hastings Beds. Sandstone with minor mudstones. Local minor aquifer. \\
\hline
\end{tabular}

Table 2. Summary statistics for BFI, and fractional area of each lithological and hydrogeological class exposed in each watershed used in regression Models 1a, 1b, and 2.

\begin{tabular}{|l|c|c|c|c|c|c|}
\hline \multicolumn{1}{|c|}{ Class } & Model & $\begin{array}{c}\text { Number of } \\
\text { observations }\end{array}$ & Minimum & Maximum & Mean & SD \\
\hline BFI & $1,2 \& 3$ & 44 & 0.190 & 0.980 & 0.648 & 0.243 \\
\hline Diamicton & $1 \& 2$ & 44 & 0.000 & 0.900 & 0.107 & 0.235 \\
\hline Chalk & $1 \& 2$ & 44 & 0.000 & 0.800 & 0.180 & 0.243 \\
\hline $\begin{array}{l}\text { Lower } \\
\text { Greensand }\end{array}$ & 2 & 44 & 0.000 & 0.656 & 0.042 & 0.132 \\
\hline Thames & $1 \& 2$ & 44 & 0.000 & 0.931 & 0.179 & 0.281 \\
\hline $\begin{array}{l}\text { Weald } \\
\text { Clay }\end{array}$ & $1 \& 2$ & 44 & 0.000 & 0.706 & 0.041 & 0.140 \\
\hline Oolites & $1 \& 2$ & 44 & 0.000 & 0.912 & 0.086 & 0.240 \\
\hline $\begin{array}{l}\text { Non- } \\
\text { permeable } \\
\text { surficial }\end{array}$ & 3 & 44 & 0.000 & 0.903 & 0.283 & 0.257 \\
\hline Aquitards & 3 & 44 & 0.000 & 0.931 & 0.267 & 0.287 \\
\hline $\begin{array}{l}\text { Sandy } \\
\text { aquifers }\end{array}$ & 3 & 44 & 0.000 & 0.857 & 0.175 & 0.192 \\
\hline $\begin{array}{l}\text { Limestone } \\
\text { aquifers }\end{array}$ & 3 & 44 & 0.000 & 0.912 & 0.274 & 0.293 \\
\hline
\end{tabular}

Table 3a. Model 1a regression.

\begin{tabular}{|l|c|c|c|c|}
\hline \multicolumn{5}{|l|}{ Model 1a: model coefficients } \\
\hline & Coefficient & Std. error & t value & $\operatorname{Pr}(>\mathbf{t})$ \\
\hline Constant & 0.640 & 0.047 & 13.700 & $<0.001$ \\
\hline Diamicton & -0.236 & 0.078 & -3.002 & 0.005 \\
\hline Chalk & 0.533 & 0.089 & 5.955 & $<0.001$ \\
\hline $\begin{array}{l}\text { Lower } \\
\text { Greensand }\end{array}$ & 0.228 & 0.119 & 1.908 & 0.064 \\
\hline Thames & -0.391 & 0.074 & -5.264 & $<0.001$ \\
\hline $\begin{array}{l}\text { Weald } \\
\text { Clay }\end{array}$ & -0.545 & 0.118 & -4.639 & $<0.001$ \\
\hline \begin{tabular}{l} 
Oolites \\
\hline \multicolumn{5}{|l|}{} & 0.229 & 0.081 & 2.835 & 0.007 \\
Model adjusted squared multiple R: 0.878 \\
Model residual standard error 0.085
\end{tabular} \\
\hline
\end{tabular}


Bloomfield et al. published in Journal of Hydrology, 373, 164-176

Table 3b. Model 1b regression.

\begin{tabular}{|l|c|c|c|c|}
\hline \multicolumn{7}{|l|}{ Model 1b: model coefficients } \\
\hline & Coefficient & Std. error & t value & Pr (>t) \\
\hline Constant & 0.693 & 0.039 & 17.676 & $<0.001$ \\
\hline Diamicton & -0.303 & 0.072 & -4.216 & $<0.001$ \\
\hline Chalk & 0.449 & 0.082 & 5.496 & $<0.001$ \\
\hline Thames & -0.462 & 0.067 & -6.884 & $<0.001$ \\
\hline $\begin{array}{l}\text { Weald } \\
\text { Clay }\end{array}$ & -0.602 & 0.119 & -5.056 & $<0.001$ \\
\hline Oolites & 0.158 & 0.075 & 2.105 & 0.042 \\
\hline \\
$\begin{array}{l}\text { Model adjusted squared multiple R: } 0.885 \\
\text { Model residual standard error } 0.088\end{array}$ \\
\hline
\end{tabular}

Table 3c. Model 2 regression.

\begin{tabular}{|l|c|c|c|c|}
\hline \multicolumn{4}{|l|}{ Model 2: model coefficients } \\
\hline & Coefficient & Std. error & t value & $\operatorname{Pr}(>\mathbf{t})$ \\
\hline $\begin{array}{l}\text { Non- } \\
\text { permeable } \\
\text { surficial }\end{array}$ & 0.557 & 0.055 & 10.105 & $<0.001$ \\
\hline $\begin{array}{l}\text { Non- } \\
\text { permeable } \\
\text { aquifers }\end{array}$ & 0.241 & 0.053 & 4.548 & $<0.001$ \\
\hline $\begin{array}{l}\text { Limestone } \\
\text { aquifers }\end{array}$ & 1.090 & 0.050 & 21.648 & $<0.001$ \\
\hline $\begin{array}{l}\text { Sandy } \\
\text { aquifers }\end{array}$ & 0.724 & 0.083 & 8.713 & $<0.001$ \\
\hline $\begin{array}{l}\text { Model adjusted squared multiple R: } 0.970 \\
\text { Model residual standard error } 0.121\end{array}$ & \\
\hline
\end{tabular}


Bloomfield et al. published in Journal of Hydrology, 373, 164-176

Table 4. Summary statistics for the bootstrap re-sampling of Model 2.

\begin{tabular}{|l|c|c|c|c|c|c|}
\hline \multicolumn{1}{|c|}{ Class } & Model & $\begin{array}{c}\text { Number of } \\
\text { re-samples }\end{array}$ & Minimum & Maximum & Mean & SD \\
\hline $\begin{array}{l}\text { Non- } \\
\text { permeable } \\
\text { surficial }\end{array}$ & 3 & 10000 & 0.382 & 0.937 & 0.565 & 0.069 \\
\hline Aquitards & 3 & 10000 & -0.026 & 0.463 & 0.243 & 0.055 \\
\hline $\begin{array}{l}\text { Sandy } \\
\text { aquifers }\end{array}$ & 3 & 10000 & -0.309 & 0.922 & 0.709 & 0.091 \\
\hline $\begin{array}{l}\text { Limestone } \\
\text { aquifers }\end{array}$ & 3 & 10000 & 0.936 & 1.441 & 1.094 & 0.055 \\
\hline
\end{tabular}

Table 5. Summary of hydraulic conductivity data used in Figure 6.

\begin{tabular}{|l|l|l|}
\hline $\begin{array}{l}\text { Lithostratigraphic } \\
\text { class }\end{array}$ & $\begin{array}{l}\text { Hydraulic } \\
\text { conductivity (m/s) }\end{array}$ & Notes \\
\hline Diamicton & $\begin{array}{l}1 \mathrm{E}-5 \text { to 1E-11 } \\
1 \mathrm{E}-8 \text { (typical value) }\end{array}$ & $\begin{array}{l}\text { Typical range for glacial till is from 1E-5 m/s } \\
\text { to 1E-11 m/s (Freeze and Cherry, 1979). } \\
\text { There is no available data for the till in the } \\
\text { north of the Thames Basin. }\end{array}$ \\
\hline Chalk & $2 \mathrm{E}-3$ to 1E-5 & $\begin{array}{l}\text { Ranges from 2E-3 m/s, a typical value in } \\
\text { valleys, to 1E-5 m/s, typical value under } \\
\text { interfluves (Allen et al. 1997) }\end{array}$ \\
\hline Lower Greensand & $9.6 \mathrm{E}-4$ & $\begin{array}{l}\text { Based on a typical transmissivity value of 250 } \\
\mathrm{m}^{2} / \mathrm{d} \text { for the Lower Greensand (Allen et al., } \\
1997) \text { and assuming and effective aquifer } \\
\text { thickness of 30 m. }\end{array}$ \\
\hline Thames & $1 \mathrm{E}-9$ & $\begin{array}{l}\text { Ranges from 3E-8 m/s to 3E-10 m/s (Ellison } \\
\text { et al., 2004) }\end{array}$ \\
\hline Weald Clay & $5.0 \mathrm{E}-10$ & $\begin{array}{l}\text { Typical range for unweathered marine clay is } \\
\text { from 1E-9 m/s to 1E-12 m/s (Freeze and } \\
\text { Cherry, 1979). }\end{array}$ \\
\hline Oolites & $8.1 \mathrm{E}-4$ & $\begin{array}{l}\text { Based on a typical transmissivity value of 350 } \\
\mathrm{m}^{2} / \mathrm{d} \text { for the Great and Inferior Oolites (Allen } \\
\text { et al. 1997) and assuming and effective } \\
\text { aquifer thickness of 50 m. }\end{array}$ \\
\hline
\end{tabular}




\section{Figures}


Fig. 1. Maps of the Thames Basin showing, (a) physiography, rivers and the 44 catchments used in the study for calibration and (b) the distribution of the 19 lithological classes used as the basis of regression Models 1a and 1b. 




Fig. 2. A schematic illustration of the regression methodology showing the iterative development of the models. Models $1 \mathrm{a}$ and $1 \mathrm{~b}$ were developed based on lithostratigraphic classification of geological mapping, and Model 2 was based on a hydrogeological interpretation of the lithological classification.



Fig. 3. Map of the Thames Basin showing the distribution of the four main hydrogeological classes used in regression Model 2. 



Fig. 4. Plots of modelled BFI against observed BFI and model residuals for the 44 calibration catchments for Models 1a, 1b, and 2. Confidence bounds on BFI values for Model 3 are based on the $5 \%$ tile and $95 \%$ tile values for a Monte Carlo simulation using bootstrap statistics for the model. 


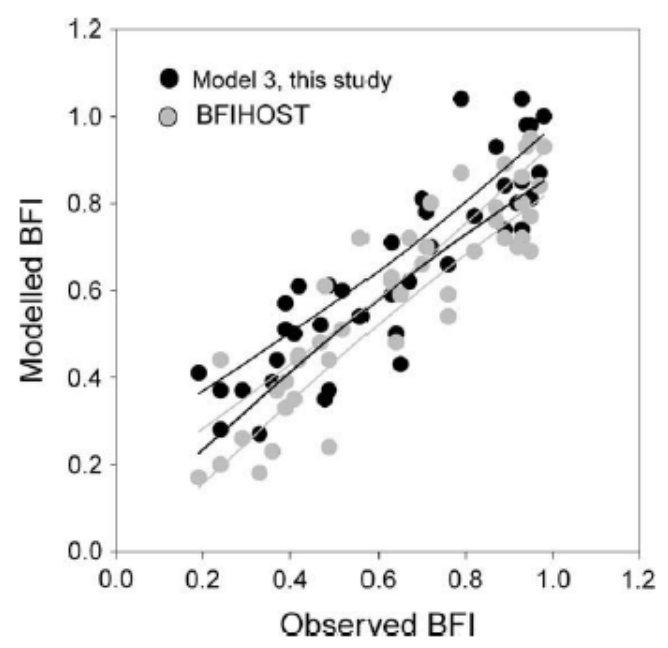

Fig. 5. Comparison between observed and modelled BFI for the 44 calibration catchments for this study and for BFIHOST. The $90 \%$ confidence bounds to linear regressions through the two respective data sets are also shown.

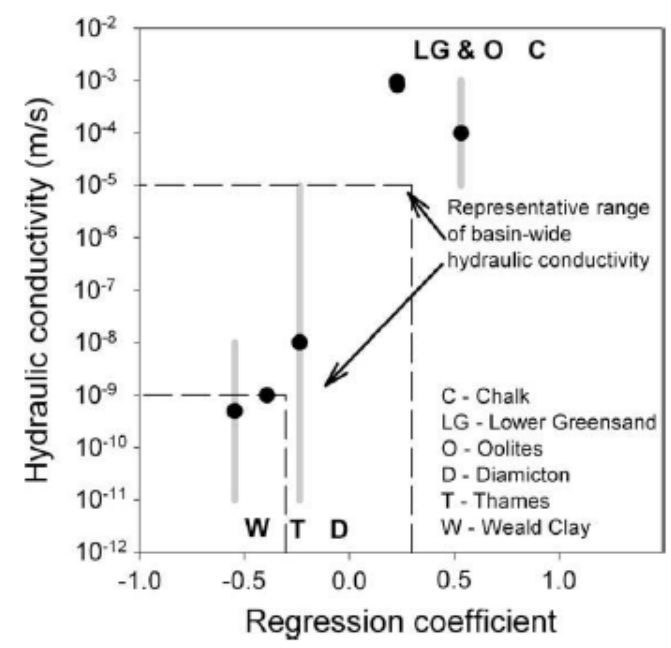

Fig. 6. Relationship between regression coefficients for Model 1a and estimates of the hydraulic conductivity for each lithostratigraphic class in the model. The dashed lines bracket the inferred range of representative hydraulic conductivity for the Basin as a whole. 


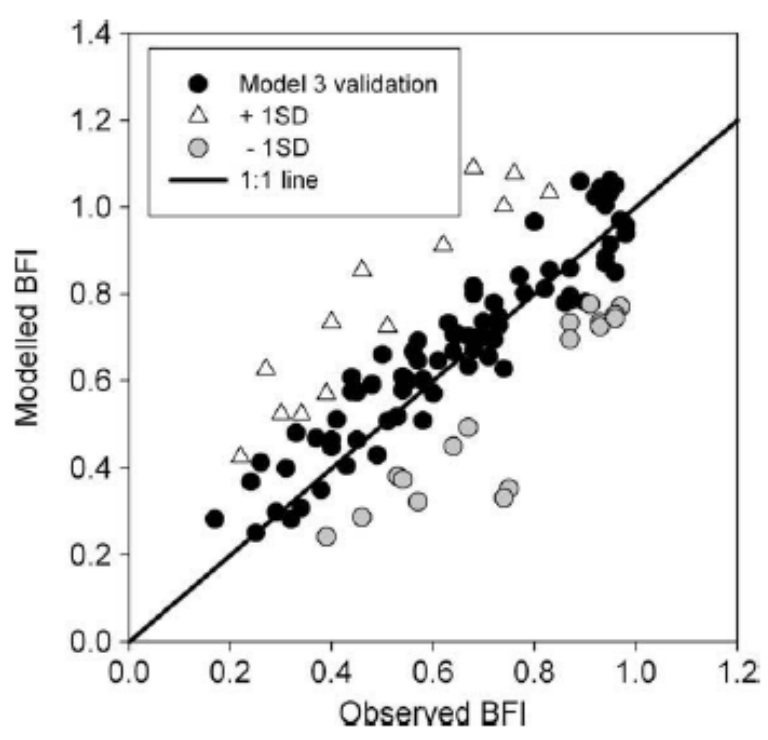

Fig. 7. Modelled against observed values of BFI for 110 'variably impacted' catchments in Thames Basin based on Model 2 with outliers identified.

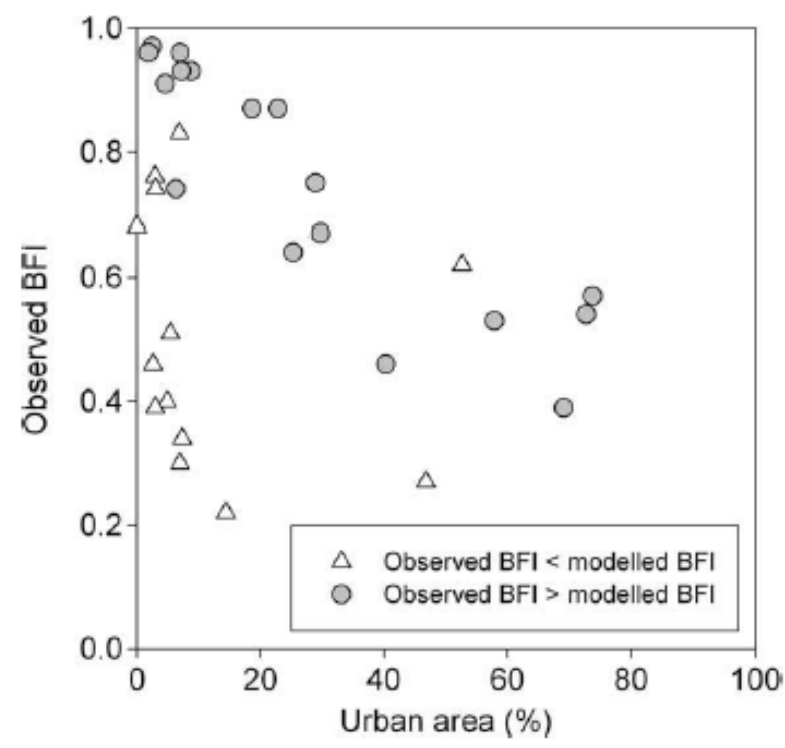

Fig. 8. Observed BFI as a function of percentage urban area for the outliers identified in Fig. 7. 